\title{
Ormosanine confers protection on neuronal function via regulation of inflammatory cytokine levels and oxidative stress
}

\author{
Juping Liang, Jicun Dong*, Yang Yang \\ Department of Internal Neurology, Wuwei People's Hospital, Wuwei 733000, Gansu Province, China
}

*For correspondence: Email: jyrbac@163.com; Tel/Fax: 0086-13197132011

Sent for review: 24 March 2020

Revised accepted: 18 April 2021

\begin{abstract}
Purpose: To investigate the neuroprotective effect of ormosanine on rat model of Alzheimer's disease $(A D)$, and the mechanism(s) of action involved.

Methods: Rats were randomly assigned to 4 groups (10 rats/group): control group, AD group, $25 \mathrm{mg}$ ormosanine/kg group, and $50 \mathrm{mg}$ ormosanine/kg group. Alzheimer's disease (AD) was induced in the rats via intracerebroventricular (ICV) injection of amyloid- $\beta$ (A 3$) 25-35$ at a concentration of $1 \mathrm{mg} / \mathrm{mL}$. Cognitive function was determined by Morris water maze test (MWMT), while lipid profile, oxidative stress parameters and cytokine level were assayed using their respective assay kits. The levels of monoamines were determined in brain tissues using high-performance liquid chromatography (HPLC), while terminal deoxynucleotidyl transferase dUTP nick end labeling (TUNEL) assay was used to determine apoptosis in neuronal cells.

Results: Cognitive function was significantly improved $(p<0.05)$ in ormosanine treated group than $A D$ group of rats. Ormosanine significantly and dose-dependently reduced lipid and cytokines levels as well as activities of AST and ALT, but it significantly increased the level of HDL-C in a dose-dependent fashion $(p<0.05)$. Moreover, ormosanine significantly and dose-dependently increased SOD activity, but reduced MDA level and neuronal cell apoptosis in brain tissues of $A D$ rats $(p<0.05)$. Treatment of $A D$ rats with ormosanine led to significant and dose-dependent increase in the levels of monoamines and $B D N F$ in rat brain tissues $(p<0.05)$.

Conclusion: These results show that ormosanine confers protection on neuronal function via regulation of inflammatory cytokine levels and oxidative stress, and therefore, could potentially be developed for the management of Alzheimer's disease.
\end{abstract}

Keywords: Amyloid- $\beta$ peptide, Apoptosis, Cognitive function, Neuro-inflammation, Alzheimer's disease, Ormosanine

This is an Open Access article that uses a fund-ing model which does not charge readers or their institutions for access and distributed under the terms of the Creative Commons Attribution License (http://creativecommons.org/licenses/by/4.0) and the Budapest Open Access Initiative (http://www.budapestopenaccessinitiative.org/read), which permit unrestricted use, distribution, and reproduction in any medium, provided the original work is properly credited.

Tropical Journal of Pharmaceutical Research is indexed by Science Citation Index (SciSearch), Scopus, International Pharmaceutical Abstract, Chemical Abstracts, Embase, Index Copernicus, EBSCO, African Index Medicus, JournalSeek, Journal Citation Reports/Science Edition, Directory of Open Access Journals (DOAJ), African Journal Online, Bioline International, Open-J-Gate and Pharmacy Abstracts

\section{INTRODUCTION}

Alzheimer's disease (AD), a chronic brain degeneration, is a major cause of dementia. It destroys memory and other important mental functions [1]. A report reveals that $A D$ is the third most cause of death of older population of United State [2]. In most patients with $A D$, symptoms first appear in the mid-60s. Although statistics vary, experts suggest that 
more than 5.5 million Americans, most of them aged 65 and above, may have AD-related dementia [2]. The pathogenesis of $A D$ is complex and has not been fully elucidated. However, it may be due to a combination of genetic, environmental and lifestyle factors. Hyper-phosphorylation of tau protein ( $p$-tau) and $A \beta$ peptide deposition are the major pathogenic changes observed clinically in the brain of population suffer from AD. However exact pathogenesis of $A D$ is still not known. Dysregulation in the metabolism of amyloid precursor protein (APP) causes Amyloid- $\beta$ (A $\beta$ ) peptide plaque formation [3]. Abnormal p-tau protein causes the formation of Neurofibrillary tangles (NFTs). Hippocampus and entorhinal cortex dysfunction occurs in the Tau pathology is followed by APP [3]. Moreover, neurotoxicity in $A D$ is due to increased oxidative stress [4]. The formation and deposition of $A \beta$ increases oxidative stress and causes impairment of cognitive functions $[5,6]$.

Studies have shown that amyloid- $\beta \quad(A \beta)_{25-35}$ causes neuronal injury via oxidation/nitration of proteins, induction of nitric oxide synthase and long-term potentiation (LTP)-like changes [7]. Deposition of $A \beta$ leads to microglia stimulation and enhanced release of inflammatory cytokines [8]. Several signals activate the microglia cells for neurotoxicity or neuroprotective effect under pathological condition [9]. Mitogen-activated protein kinase (MAPK)-dependent pathways have been demonstrated to contribute to neuroinflammation [9]. The conventional drugs used for the management of neuro-inflammation and $A D$ have several limitations.

Medicines from the natural origin shows promising effect in the management of several disorders. Ormosanine is a pentacyclic alkaloid isolated from Akebia quinata [10]. It possesses antimalarial, analgesic, sedative, hypnotic and liver- protective effects $[11,12]$. The hepatoprotective effect of ormosanine is exerted via modulation of MAPK pathway as well as regulation of oxidative stress [13]. Investigated report presented here shows the beneficial effect of ormosanine on rat model of $A D$, and the mechanism(s) involved.

\section{EXPERIMENTAL}

\section{Rats}

Forty male Sprague Dawley rats $(250-300 \mathrm{~g})$ were housed (Temperature: $24 \pm 3{ }^{\circ} \mathrm{C}, 12-\mathrm{h}$ light/12-h dark cycle and Humidity: $60 \pm 5 \%$ ) as per the guidelines of Association for the
Assessment and Accreditation of Laboratory Animal Care International (AAALAC) [14].The study protocol was approved by the Institutional Animal Care and Use Committee of Wuwei People's Hospital, China (approval no. IAEC/WPH/09/2018).

\section{Experimental design}

The rats were randomly assigned to 4 groups (10 rats/group): control group, AD group, $25 \mathrm{mg}$ ormosanine/kg group and $50 \mathrm{mg}$ ormosanine/kg group. Alzheimer's disease (AD) was induced in the rats via ICV injection of $A \beta_{25-35}$ at a concentration of $1 \mathrm{mg} / \mathrm{mL}$ under ketamine (90 $\mathrm{mg} / \mathrm{kg}$ bwt) anesthesia. The rats were placed on stereotaxic apparatus to maintain their body temperature while being anesthetized. The injection point was stereotaxically located: $3 \mathrm{~mm}$ dorsal, $\pm 2.3 \mathrm{~mm}$ lateral and $-3.6 \mathrm{~mm}$ posterior. The $A \beta_{25-35}$ was administered bilaterally and reflux was prevented by keeping the needle in place for $2 \mathrm{~min}$. After AD induction, the rats were placed on warm pad for 14 days to recover and maintain their sternal recumbencies. Rats in the treatment groups received ormosanine at doses of 25 and $50 \mathrm{mg} / \mathrm{kg}$ p.o. for 21 days. Behavioral analysis was carried out using MWMT.

\section{Morris water maze test (MWMT)}

MWMT was used to determine the spatial learning, MWMT apparatus was divided into equal quadrants. Platform was placed in such a manner so that rat is not able to see the platform on the surface of water. Rats were trialed for a week and between 3-4 h each day trail was given in two session. Rats were allowed to swim, and data was observed by determining the time spent in the target quadrant after removing the platform [14].

\section{Measurement of serum markers of atherosclerosis}

Peripheral venous blood was drawn from retroorbital plexus of each rat and serum was separated by centrifuge the blood for $10 \mathrm{~min}$ at $13,000 \mathrm{rpm}$ at $4{ }^{\circ} \mathrm{C}$. The levels of TC, LDL-C, and $\mathrm{HDL}-\mathrm{C}$ were assayed in serum using automated biochemical analyzer, ALT and AST activity were estimated using their respective assay kits.

\section{Determination of levels of inflammatory cytokines and BDNF}

Levels of NF-kB, IL-1 $\beta, I L-6$ and TNF- $\alpha$ in the serum and level of BDNF in the tissue were determined using their respective ELISA kits. 


\section{Measurement of oxidative status of AD rats}

Standard assay method was used to observe the activity of SOD and level of MDA in AD rats.

\section{Determination of levels of monoamines}

The levels of monoamines in brain tissue were determined using HPLC. High-performance liquid chromatography (HPLC) setup with autosampler AS-1555 and RP18 analytical column ( $\mathrm{C}-18$ guard column made of Thermosil) was used for the separation of monoamines. A mixture of dibutyl amine $(0.01 \%, v / v), 0.2 \mathrm{M}$ EDTA, $0.055 \%$ heptane sulphonic acid, $16 \%$ methanol and $0.02 \mathrm{M}$ sodium acetate was used as mobile phase. The resolution peaks were recorded with Borwin chromatographic software. The levels of $5-\mathrm{HT}, \mathrm{DA}$ and NA were determined using a fluorescent detector at 280 and $315 \mathrm{~nm}$.

\section{Neuronal apoptosis assay}

Apoptosis in the hippocampal tissue was assessed by TUNEL assay. The excised brain tissues were fixed in formaldehyde at $4{ }^{\circ} \mathrm{C}$ for 5 $\mathrm{h}$ and subsequently embedded in paraffin. The embedded tissues were then sliced into thin 2$\mu \mathrm{m}$ sections using a refrigerated microtome. Fluorometric dead end TUNEL kit was used for the determination of TUNEL-positive cell population. Inverted Eclipse Ti2 microscope was used for analysis of the TUNEL-positive cells in rat brain tissues.

\section{Statistical analysis}

The data are presented as mean \pm standard error mean (SEM, $n=10)$. One-way analysis of variance (ANOVA) followed by Dunnett's post hoc test was applied for statistical analysis by using GraphPad Prism software (ver 6.1; San Diego, CA, USA). Statistical significance was indicated having the $p<0.05$.

\section{RESULTS}

\section{Effect of ormosanine on rat cognitive function}

In $A D$ group rats, time spent in the target quadrant, number of crossings and escape latency were reduced significantly than in control group (Figure 1). However, ormosanine treatment significantly $(p<0.05)$ and dose dependently enhances these parameters.

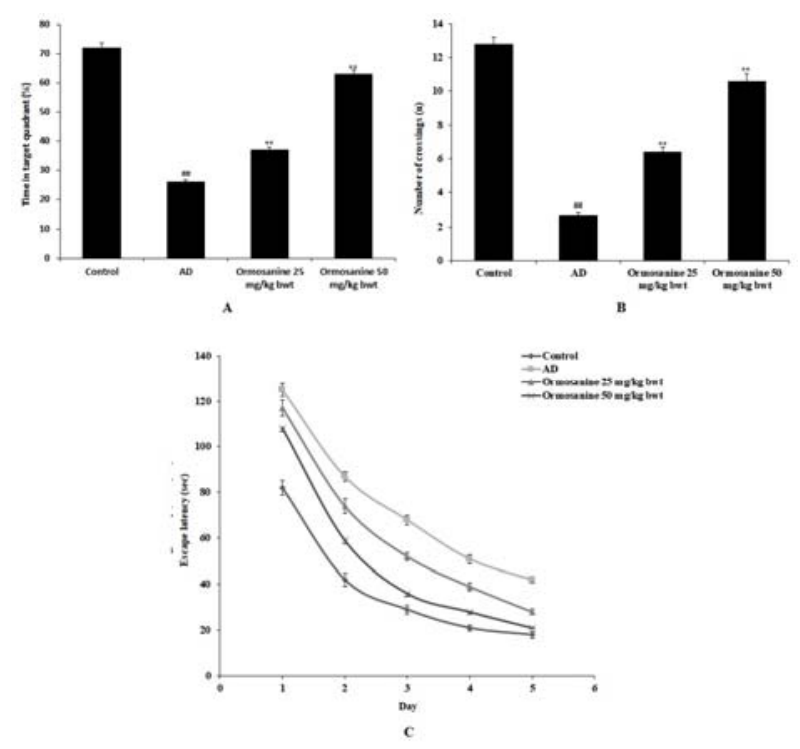

Figure 1: Effect of ormosanine on rat cognitive function. (A): Time spent in target quadrant; (B): Number of crossings; and (C): Escape latency of rats. ${ }^{\#} P<0.05$, compared with control group; ${ }^{* *} p<0.05$, than AD group

\section{Effect of ormosanine on liver function indices and lipid profile}

Ormosanine significantly and dose-dependently reduced the levels of LDL-C, TC as well as activities of AST and ALT, but it significantly increased $(p<0.05)$ the level of HDL-C in a dose-dependent fashion (Table 1).

Table 1: Effect of ormosanine on liver function indices and lipid profiles

\begin{tabular}{|c|c|c|c|c|c|}
\hline Group & $\begin{array}{l}\text { HDL-C } \\
\text { (mg/dL) }\end{array}$ & $\begin{array}{l}\text { LDL-C } \\
\text { (mg/dL) }\end{array}$ & $\begin{array}{c}\text { TC } \\
(\mathrm{mg} / \mathrm{dL})\end{array}$ & AST (U/L) & ALT (U/L) \\
\hline Control & $17.80 \pm 1.04$ & $76.40 \pm 4.20$ & $503.90 \pm 14.80$ & $114.60 \pm 4.27$ & $38.72 \pm 1.63$ \\
\hline$A D$ & $8.46 \pm 0.86^{\# \#}$ & $251.90 \pm 10.50^{\# \#}$ & $1206.00 \pm 37.10^{\# \#}$ & $239.30 \pm 8.61^{\# \#}$ & $107.40 \pm 3.82 \# \#$ \\
\hline Ormosanine (25 mg/kg) & $11.50 \pm 0.92^{\star *}$ & $171.00 \pm 8.20^{* *}$ & $901.50 \pm 20.90^{* *}$ & $186.40 \pm 6.92^{\star *}$ & $71.37 \pm 3.16^{\star *}$ \\
\hline Ormosanine $(50 \mathrm{mg} / \mathrm{kg})$ & $14.90 \pm 0.63^{* *}$ & $96.20 \pm 6.80^{* *}$ & $658.40 \pm 17.30^{* *}$ & $137.10 \pm 4.95^{\star \star}$ & $51.69 \pm 2.03^{* *}$ \\
\hline
\end{tabular}


Effect of ormosanine on indices of oxidative stress

As shown in Figure 2, ormosanine significantly and dose-dependently increased SOD activity, while it significantly reduced MDA level in $A D$ rats $(p<0.05)$.
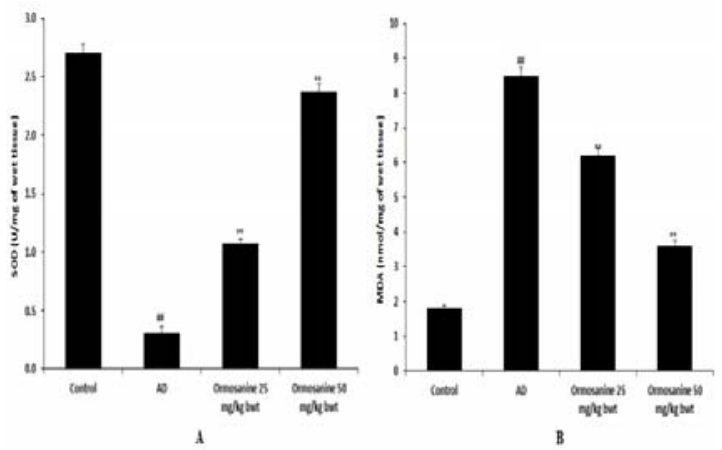

Figure 2: Effect of ormosanine on indices of oxidative stress. (A): Activity of SOD in brain tissue; (B): Level of MDA in brain tissue. ${ }^{\#} P<0.05$, compared with control group; ${ }^{* *} p<0.05$, than AD group

\section{Effect of ormosanine on levels of inflammatory cytokines}

Treatment of $A D$ rats with ormosanine led to significant and dose-dependent reductions in the levels of circulating IL-1 $\beta, \mathrm{IL}-6, \mathrm{TNF}-\alpha$ and NF-kB $(p<0.05$; Figure 3$)$.

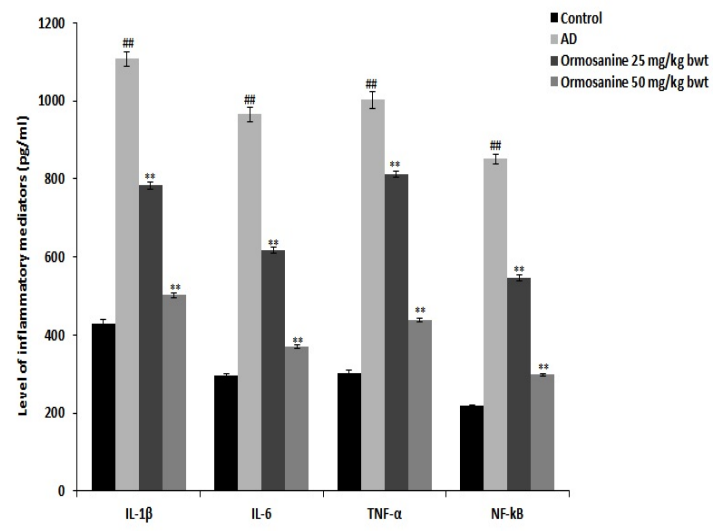

Figure 3: Effect of ormosanine on levels of inflammatory cytokines. ${ }^{\# \#} P<0.05$, than control group; ${ }^{* *} p<0.05$, compared with $\mathrm{AD}$ group

Effect of ormosanine on the levels of monoamines in rat brain tissues

As shown in Figure 4, treatment of $A D$ rats with ormosanine led to significant and dosedependent increases in brain tissue levels of NA, DA and $5-\mathrm{HT}(p<0.05)$.

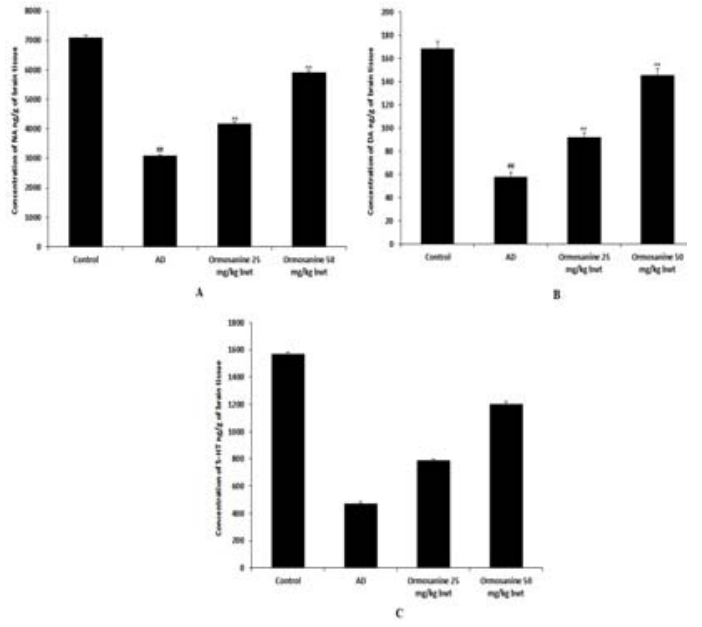

Figure 4: Effect of ormosanine on the levels of monoamines in rat brain tissues. (A): NA; (B): DA; and (C): $5-\mathrm{HT} . \quad \# P<0.05$, compared with control group; ** $p<0.05$, compared with AD group

\section{Effect of ormosanine on neuronal cell apoptosis}

Neuronal cell apoptosis was significantly and dose-dependently reduced by ormosanine treatment $(p<0.05$; Figure 5).

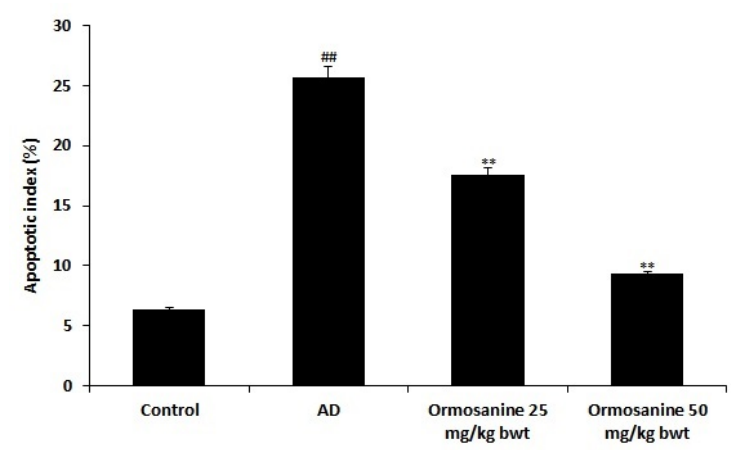

Figure 5: Effect of ormosanine on neuronal cell apoptosis. ${ }^{\#} P<0.05$, compared with control group; ${ }^{* *} p<0.05$, than AD group

\section{Effect of ormosanine on BDNF}

As shown in Figure 6, treatment of $A D$ rats with ormosanine led to significant and dosedependent increase in BDNF levels $(p<0.05)$.

\section{DISCUSSION}

Cognitive dysfunction occurs due to neurodegeneration in AD. Studies have shown that neuro-inflammation contributes significantly to the pathogenesis of $A D$ [15]. The limited effectiveness of drugs currently used for the management of $A D$ has necessitated the search 
for novel compounds that can effectively alleviate the symptoms of AD.

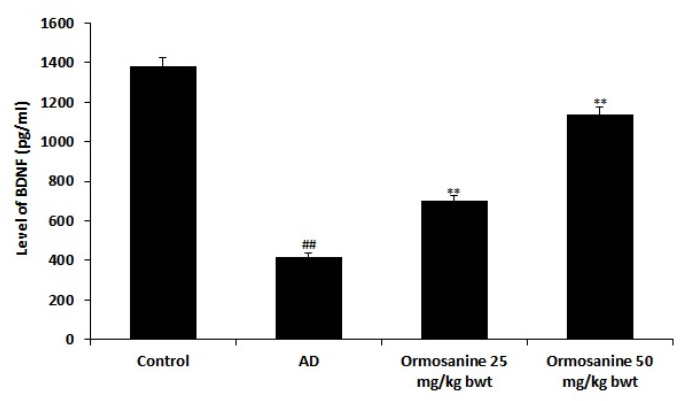

Figure 6: Effect of ormosanine on BDNF level. ${ }^{\# \#} P<$ 0.05 , compared with control group; ${ }^{* *} p<0.05$, than $A D$ group

The present study investigated the neuroprotective effect of ormosanine on a rat model of $A D$, and the mechanism(s) involved. It has been reported that deposition of $A \beta$ peptide produces toxic effect on neurons and leads to impairment of cognitive functions [16]. Amyloid plaque contains $A \beta$ peptide in the brain tissue of patients suffering from AD 17]. Amyloid- $\beta(A \beta)^{25-}$ 35 is used experimentally to induce $A D$ since it is well established that it causes cognitive impairment. The results of MWMT demonstrated that ormosanine significantly enhanced cognitive function in brain tissues of rats with $A D$.

There are several pathogenic factors involved in the development of $A D$ including cytokine and oxidative stress [18]. Neuronal injury occurs due to imbalance between levels of antioxidant molecules and reactive oxygen species. Molecules that can significantly reduce oxidative stress have been shown to exert neuroprotective effects [19]. In this study, ormosanine significantly reversed the $A D$ induced changes in oxidative stress. These results agree with those from previous reports [19]. It is likely that the neuroprotective effect of ormosanine is attributable to its antioxidant property. Oxidative stress enhances the synthesis and release of inflammatory cytokines, which in turn cause neuronal cell injury and apoptosis [18]. The results of this study showed that ormosanine reduces the levels of cytokines, an indication that the crude drug may possess anti-inflammatory effect. Monoamines are vital for maintenance of cognitive function [20]. They are implicated in various cognitive processes such as memory and executive functions. In this study, treatment of $A D$ rats with ormosanine led to enhancement of levels of NA, DA and $5-\mathrm{HT}$.

During inflammation, BDNF, a relatively mature neurotrophic factor, promotes the proliferation of neurons and glial cells via various molecular mechanisms. It plays an important role in brain development. The level of BDNF is usually altered when there is cognitive impairment [21]. The results of this study indicate that ormosanine may enhance the level of BDNF in brain tissues of $A D$ rats and are in agreement with those of previous reports.

\section{CONCLUSION}

The results obtained in this study show that ormosanine confers protection on neuronal function via regulation of inflammatory cytokine levels and oxidative stress. Thus, ormosanine can potentially be developed for the treatment of AD.

\section{DECLARATIONS}

\section{Acknowledgement}

The authors are thankful to Wuwei People's Hospital, China for providing the facilities to conduct this work.

\section{Conflict of interest}

No conflict of interest is associated with this work.

\section{Contribution of authors}

We declare that this work was done by the authors named in this article and all liabilities pertaining to claims relating to the content of this article will be borne by the authors. Juping Liang performs the experimental work and contributes in the development of protocol. Jicun Dong contributes in the data collection, designed the work, write the manuscript and supervised it. Yang Yang performs stastical analysis and histopathology analysis.

\section{Open Access}

This is an Open Access article that uses a funding model which does not charge readers or their institutions for access and distributed under the terms of the Creative Commons Attribution License (http://creativecommons.org/licenses/by/ 4.0) and the Budapest Open Access Initiative (http://www.budapestopenaccessinitiative.org/rea d), which permit unrestricted use, distribution, and reproduction in any medium, provided the original work is properly credited.

Trop J Pharm Res, May 2021; 20(5): 951 


\section{REFERENCES}

1. Moya-Alvarado G, Gershoni-Emek N, Perlson E, Bronfman FC. Neurodegeneration and Alzheimer's disease (AD). What Can Proteomics Tell Us About the Alzheimer's Brain? Mol Cell Proteomics 2016; 15(2): 409-425.

2. Alzheimer's Association. 2016 Alzheimer's disease facts and figures. Alzheimer's Dement 2016; 12(4):459-509.

3. Rajmohan $R$, Reddy PH. Amyloid-Beta and Phosphorylated Tau Accumulations Cause Abnormalities at Synapses of Alzheimer's disease Neurons. J Alzheimers Dis. 2017; 57(4): 975-999.

4. Salim S. Oxidative Stress and the Central Nervous System. J Pharmacol Exp Ther. 2017; 360(1): 201-205.

5. O'Brien RJ, Wong PC. Amyloid precursor protein processing and Alzheimer's disease. Annu Rev Neurosci. 2011; 34: 185-204.

6. Butterfield DA, Boyd-Kimball D. Oxidative Stress, Amyloid- $\beta$ Peptide, and Altered Key Molecular Pathways in the Pathogenesis and Progression of Alzheimer's Disease. J Alzheimers Dis. 2018; 62(3): 1345-1367.

7. Butterfield DA, Reed T, Newman SF, Sultana R. Roles of amyloid beta-peptide-associated oxidative stress and brain protein modifications in the pathogenesis of Alzheimer's disease and mild cognitive impairment. Free Radic Biol Med. 2007; 43(5): 658-677.

8. Wang WY, Tan MS, Yu JT, Tan L. Role of proinflammatory cytokines released from microglia in Alzheimer's disease. Ann Transl Med. 2015; 3(10): 136.

9. Park SE, Sapkota K, Kim S, Kim H, Kim SJ. Kaempferol acts through mitogen-activated protein kinases and protein kinase B/AKT to elicit protection in a model of neuroinflammation in BV2 microglial cells. $\mathrm{Br} \mathrm{J}$ Pharmacol. 2011; 164(3): 1008-1025.

10. Jung HJ, Lee CO, Lee KT, Choi J, Park HJ. Structureactivity relationship of oleanane disaccharides isolated from Akebia quinata versus cytotoxicity against cancer cells and NO inhibition. Biol Pharm Bull. 2004; 27(5): 744-747.

11. Lee SH, Song YS, Jeong Y, Ko KS. Antioxidative and Anti-Inflammatory Activities of Akebia quinata Extracts in an In Vitro Model of Acute Alcohol-Induced Hepatotoxicity. J Med Food. 2017; 20(9): 912-922.

12. Al-Mariri A, Safi M. In Vitro Antibacterial Activity of Several Plant Extracts and Oils against Some GramNegative Bacteria. Iran J Med Sci. 2014; 39(1): 36-43.
13. Song $D H$, Kim GJ, Chung $K H$, Lee KJ, An JH, Ormosanine from Akebia quinata suppresses ethanolinduced inflammation and apoptosis and activates antioxidants via the mitogen activated protein kinase signaling pathway. J. Funct. Foods, 2018; 48: 357-366.

14. Guide for the Care and Use of Laboratory Animals: Eighth Edition Committee for the Update of the Guide for the Care and Use of Laboratory Animals; National Research Council. 2010; ISBN: 0-309-15401-4.

15. Qin H, Qin J, Hu J, Huang H, Ma L. Malva Sylvestris Attenuates Cognitive Deficits in a Repetitive Mild Traumatic Brain Injury Rat Model by Reducing Neuronal Degeneration and Astrocytosis in the Hippocampus. Med Sci Monit. 2017; 23: 6099-6106.

16. Ardura-Fabregat A, Boddeke EWGM, Boza-Serrano A, Brioschi S, Castro-Gomez S, Ceyzériat K, Dansokho C, Dierkes T, Gelders G, Heneka MT, Hoeijmakers L, Hoffmann A, laccarino $L$, Jahnert $S$, Kuhbandner $K$, Landreth G, Lonnemann N, Löschmann PA, McManus RM, Paulus A, Reemst K, Sanchez-Caro JM, Tiberi A, Van der Perren A, Vautheny A, Venegas $C$, Webers $A$, Weydt $P$, Wijasa TS, Xiang $X$, Yang Y. Targeting Neuroinflammation to Treat Alzheimer's Disease. CNS Drugs. 2017; 31(12): 1057-1082.

17. Mucke L, Selkoe DJ. Neurotoxicity of amyloid $\beta$-protein: synaptic and network dysfunction. Cold Spring Harb Perspect Med. 2012; 2(7): a006338.

18. Ghumatkar PJ, Patil SP, Peshattiwar V, Vijaykumar T, Dighe $V$, Vanage $G$, Sathaye $S$. The modulatory role of phloretin in Aß25-35 induced sporadic Alzheimer's disease in rat model. Naunyn Schmiedebergs Arch Pharmacol. 2019; 392(3): 327-339.

19. Tönnies E, Trushina E. Oxidative Stress, Synaptic Dysfunction, and Alzheimer's Disease. J Alzheimers Dis. 2017; 57(4): 1105-1121.

20. Uttara B, Singh AV, Zamboni P, Mahajan RT. Oxidative stress and neurodegenerative diseases: a review of upstream and downstream antioxidant therapeutic options. Curr Neuropharmacol. 2009; 7(1): 65-74.

21. Sartori $A C$, Vance $D E$, Slater $L Z$, Crowe $M$. The impact of inflammation on cognitive function in older adults: implications for healthcare practice and research. J Neurosci Nurs. 2012; 44(4): 206-217.

22. Miranda M, Morici JF, Zanoni MB, Bekinschtein P. BrainDerived Neurotrophic Factor: A Key Molecule for Memory in the Healthy and the Pathological Brain. Front Cell Neurosci. 2019; 13: 363. 